\begin{tabular}{|c|c|}
\hline 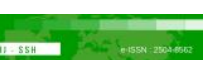 & Malaysian Journal of Social Sciences and Humanities (MJSSH) \\
\hline Malaysian Journal of & Volume 6, Issue 6, June 2021 \\
\hline (mJ-ssH) & e-ISSN : 2504-8562 \\
\hline & $\begin{array}{l}\text { Journal home page: } \\
\text { www.msocialsciences.com }\end{array}$ \\
\hline
\end{tabular}

\title{
Law Enforcement Principle in Islamic Ruling on Zakat Distribution to Transexuals, Prostitutes and Gigolos
}

\author{
Mohd Izhar Ariff Mohd Kashim¹, Nurul Ilyana Muhd Adnan', Hafizuddin Muhd Adnan², \\ Nurul Izwah Muhd Adnan ${ }^{3}$ \\ ${ }^{1}$ Research Centre for Sharia, Faculty of Islamic Studies, Universiti Kebangsaan Malaysia (UKM) \\ ${ }^{2}$ Department of Computer Sciences, Kulliyyah of Information \& Communication Technology, International Islamic \\ University Malaysia (IIUM), P.O. Box 10, 50728, Kuala Lumpur, Malaysia \\ 3Department of Library and Information Sciences, Kulliyyah of Information \& Communication Technology, \\ International Islamic University Malaysia (IIUM), P.O. Box 10, 50728, Kuala Lumpur, Malaysia
}

Correspondence: Nurul Ilyana Muhd Adnan (ilyana_adnan@ukm.edu.my)

\begin{abstract}
Surah al-Taubah Verse 60 mention that there are eight eligible persons to receive Zakat. They are the poor and the needy, amil (those employed to collect zakah), muallaf (those bringing hearts together for Islam), al-riqab (those in captives or slaves), al-gharimin (those in debt), fi sabilillah (those in the cause [way] of Allah) and ibn sabil (the [stranded] traveller). Al-riqab is the fifth from eight eligible persons to receive Zakat. Currently, the provision of zakat to the al-riqab (slave) is allocated into other asnaf as the slave is not existed in Malaysia. However, there are several states such as Selangor, Negeri Sembilan, Terengganu and Melaka have broadened the definition of al-riqab to individuals who wish to come out of the shackles of ignorance and social problems. The individuals are transsexuals, prostitutes and gigolos. However, some of other states rejected the fatwa of these states. This article is aimed to identifying the nature of the transsexuals, prostitutes and gigolos who are included in the al-riqab group. It is also intended to analyze the principles in law enforcement of this group (transsexuals, prostitutes and gigolos) which is categorized as al-riqab. This research uses the document analysis method such as Tafsir books, fiqh of four Sects and journals. Data is analyzed through thematic content analysis. The result shows the transsexuals, prostitutes and gigolos qualified to be considered to receive zakat aid under al-riqab. However, it must be based on the criteria and conditions stipulated by the country. The fatwa is designed to ensure that they are able to get out of the crisis and continue to live in a better life. In addition, it is also intended to ensure the asnaf of zakat in the al-Quran testimonial remains relevant at all times. Therefore, the zakat management in Malaysia should undertake the provision of al-riqab systematically and well organized to avoid any conflicts with Islamic principles. This will be uphold the dignity of the zakat institutions and Islam as a religion of Rahmatan lil Alamin.
\end{abstract}

Keywords: the principle of Islamic rullings, zakat, al-riqab, transsexual, prostitute, gigolo

\section{Introduction}

The civilization enrichment currently seen is caused by rapid growth from the beginning of human civilisation until nowadays. However, there are some discordant activities occurred in the past still happen nowadays although it is clear that it is a wrongdoing. In addition, it violates the law of syara' and 
the way of life. Such behaviors are illicit behaviours for instance, transexuals, prostitutes and gigolos. It is not a new phenomenon in human life (Julian 1980). Based on the statement from them that their behaviour is caused by the enforcement of feelings or desires that drive them coping with the wrongdoing. According to SUHAKAM (2014), a total 20 out of 64 respondents worked as sex workers as a fulltime job. While 15 out of 45 respondents made it a part time job. In order to help these groups from continuing living in discordant life, alternatively countering it through the zakat. The question is, what are the principles of determination of Islamic law against the distribution of zakat into transexuals, prostitutes and gigolos.

\section{Literature Review}

\section{Definition of Zakat}

Zakat is a word of derivatives from the phrase (j) means sacred and fertile, including clean, blessings, growing, toward zakat properties, zakat payers, and zakat recipients. In terms of technical meaning, zakat is to produce certain properties at a certain rate according to certain conditions to be distributed to certain groups. (Sabiq Sayid, 1981)

Allah SWT says:

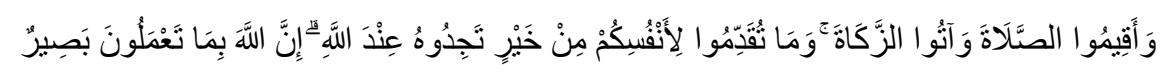

\footnotetext{
Means: "Establish prayer and pay alms-tax. Whatever good you send forth for yourselves, you will 'certainly" find 'its reward' with Allah. Surely Allah is All-Seeing of what you do." (al-Baqarah 2: 110)
}

In this verse, Allah encouraged the believers to busy themselves in performing deeds that would bring them benefit and reward on the Day of Resurrection, such as prayer and paying Zakah. This way, they will gain Allah's aid in this life and on a Day when the witnesses testify (Ibn Kathir 2003).

Moreover, zakat is the term of a determination deducted from the property in its different forms and from our body. Zakat according to etymology is sacred, growing, blessed and praise. Zakat on property is a cleaning agent against the property, until it is full of blessing. And zakat fitrah is a cleanser against the body that doing it. (Mutawalli 2012).

Islam has established with full of wisdom, and the objectives from the obligation to pay zakat is to assist the development of Muslims. Zakat that professionally and transparently managed, will emerge as the main source of financing to achieve the welfare and development goals of Muslims (Mohd Sulaiman Zahlan, Zainal Fikri Zamzuri, Mohd Fauzi Md Isa \& Wahairi Mahmud 2010).

\section{Definition of Transexuals, Prostitutes and Gigolos}

\section{Transexuals}

According to the Kamus Dewan, 4th Edition (2010), transexuals is male or female with the feeling and impose their behaviour contrary of their gender, and sometimes changes his gender organ through surgery. These groups are also known as transsexuals or mukhannaths. In Arabic, the word mukhannath means broken and bent (Ibn Manzur, 1999). Mukhannath also means having two gentle qualities. Meaning, a person who has many feminine and gentle qualities. According to Mu'jam Lughat al-Fuqaha' (1988), mukhannath means a man who is like a woman in the way he walks, his words, his emotions and his gentleness. 
Narrated Ibn Abbas R.A:

Rasulullah SAW cursed men who resembled women from among men and cursed those who resembled men from among women, then Prophet SAW said: remove (expel) them from your houses, then Prophet SAW removed Fulan and Umar issued Fulan (Sahih Bukhari No. 333).

According to An Nawawi (Sharbiniy 1994), this hadith is addressed to a transexuals who deliberately resembles a woman and he chooses by that nature. The Prophet S.A.W has given a specialization to the transvestites that they cannot mix with the community, except one day a week, which is on Friday.

These groups are called inverse as they behave against the real gender. These people often feel if they are a female, they should be male. If they are a man, then supposedly a woman (Lerner, 2006). These people assume that their gender identity is supposed to differ from what matches their sex organ physiologically (Lerner, 2006).

\section{Prostitutes}

According to the 4th edition of the Kamus Dewan (2010), prostitutes are those who slut or who are selfprostituting. In this context, it has various meaning. Many said that the prostitution is a sexual relationship that is sold, not given "promiscuous" and "without obligations". Payment can be made with money or goods (May, 19333: 553; Gagnon, 1958: 592; Benjamin, 1950: 869; Elliot \& Merril, 1941: 155; Sanford, 1997: 30; James, 1977: 369). Specifically, this act was carried out by women (Morris \& Hawkins, 1970: 20; Encyclopedia Britannica). The Women and Girls Protection Act, 1973 interprets prostitution as: "the act of a woman offering her body for a random sexual relationship by a rents of, either money or goods and "prostitutes" shall be interpreted accordingly".

Narrated Abdullah ibn Abbas:

The Prophet S.A.W said: There is no prostitution in Islam. If anyone practised prostitution in pre-Islamic times, the child will be attributed to the master (of the slave-woman). He who claims his child without a valid marriage or ownership will neither inherit nor be inherited (Sunan Abu Dawood No. 2257).

This hadith showed that prostitution is a form of adultery in Islam. If someone committed adultery, they should be punished because it is a crime against Allah. Most of the rules related to fornication, adultery and false accusations from a husband to his wife or from members of the community to chaste women, can be found in Surah an-Nur: 2, 4, 5 .

\section{Gigolos}

According to the 4th edition of Kamus Dewan (2010), gigolo is a upsuance person preserved by a woman as his friend or lover. Nichols (1981) states gigolo is a trader providing the pleasure services that women need by selling themselves. They consider themselves a high-quality commodity. They do not place emotional claims beyond these commercial claims.

Gigolos also referred to as male prostitutes, especially when the male prostitute is an adult. There are several factors that motivate this group to get involved in such activities. The factors are association with those involved in prostitution or related activities, employment in sex-related services, previous coital experience, high financial returns, broken homes \& childhood abuse, poverty and human trafficking (Kanapathy 2012).

The Qur'an and the Sunna indeed explain in detail the sexual practices between spouses, who are described in the Islamic scriptures as "garments" fitting each other. Outside of a lawful marriage, as prescribed by the Sharia, no other form of sexual activity is permissible. In accordance with the classical understanding of the Sharia, any extra-marital (i.e.,unlawful) sexual relations are illegal, with 
corresponding criminal law sanctions. Unlawful sexual intercourse is identified as zina, which is a major offense (Rehman \& Polymenopoulou 2013).

\section{Methodology}

This qualitative study used document analysis methods to identify the nature of the transexuals, prostitutes and gigolos included in the riqab group. The method of document analysis is also used to analyze the principles of determination of the islamic law of the group which is devoted to riqab. The documents analyzed are tafsir books, four madhhab fiqhs and journals. The data obtained is analyzed through thematic content analysis.

\section{Result}

\section{Zakat law to Al-Riqab}

\section{Opinions of Previous Scholars and Current Fatwas on The Ruling of Zakat al-Riqab}

In the current context, the issue arise is about distribution of zakat to transexuals, prostitutes and gigolos (Muna 2020). The distribution of zakat to these groups belongs to asnaf al-riqab for the purpose of recuring them to return to the original nature. In this chapter, it will be stated on the ruling of zakat alriqab according to previous scholars and contemporary scholars.

There are differences in opinions of scholars who define asnaf al-riqab in the current context. This can be seen from various angles and dimensions. According to contemporary interpretations, the definition of mukatab slaves, slaves and disbelioted Muslims with exploited characteristics until enslaved.

According to the opinion of the scholars, the 'al-riqab' which is eligible to receive zakat is only the mukatab slave which is a slave to be released and he is Muslim. Mutual scholar's opinion mention that it is a must and it should give some zakat to the owner of the slave to released (free) the slave and be able to settle all his debts. Apart from slaves such as administrative slave, istilads or tab'idh are not allowed to use zakat properties to purchase a slave and then released he or she later on. This opinion is from Ali bin Abi Talib, Sa'id bin Jubayr, al-Layth, al-Thauri, scholars Hanfiyah and Syafi'iyah. (alMarghinani, 1990; Ibn al-Humam, 1995; al-Zayla'i, 2000; al-Babarti, 2007; Badr al-Din al-'Aini, 2000; Ibn 'Abidin, 1998; al-Khatib, 2008; al-Nawawi, 2000; Zakaria al-Ansari, 2001; al-Baijuri, 1999; alMalbari, 2009; al-Bujairimi, 1996; Muhammad 'Abduh and Muhammad Rashid Reda, 2002; alMawsu'ah al-Fiqhiyah, 1990).

Meanwhile, some opinion from scholar is that al-riqab eligible to receive zakat is only a slave which is to released them using zakat property. This opinion is by Ibnu 'Abbas, Hasan al-Basri, Malik, Ahmad, Abu Thaur, Abu 'Ubayd, al-Bukhari, Ibnu Manzur, and Malikiyyah scholars. They argued by saying that if al-riqab was referred to as a mukatab slave, then it was included in the al-gharimin category as he owed his debtor. While according to madhhad Hanafi, Syafi'i and one of Imam Ahmad's opinions, the act is not permitted (al-Qurafi, 2008; al-Khurasyi, 1997; al-Dusuqi, 2003; Muhammad 'Abduh and Muhammad Rashid Reda, 2002; al-Mawsu'ah al-Fiqhiyah, 1990).

Some of the scholars, from the narrations of Imam Ahmad, Ibn Habib of madhhab Hambali, Ibn 'Abdul Hakam of Maliki, Fakhruddin al-Razi and Ibn Taimiyyah, saying that apart from freeing slaves, it is permissible to use part of the zakat property for the purpose of redemption of war prisoner (al-asir) who are Muslims from disbelievers (Kafir). It is the priority of releasing Muslim captives rather than releasing legitimate slaves owned by Muslims which is considered as a worship and charity (al-Qurtubi, 1993; al-Qurafi, 2008; Ibn Qudamah, 1994; Ibn Muflih, 1997; al-Bahuti, 1996; Ibn Najjar, 1999; alMawsu'ah al-Fiqhiyah, 1990). 
According to the Selangor State Fatwa Council's Power of Office meeting on 16 March 2011 and decided that the ruling on the use of asnaf ar-riqab zakat money is permissible for those who are shackled by social problems in ensuring Muslims faith is revert. The use of Asnaf al-Riqab zakat money is based on the following mechanisms (Unknown 2011):

Criteria

i. There are not enough financial resources and/or does not receive any assistance from other sources.

ii. A person who has been confirmed wants to free himself from the shackles he faced.

\author{
Distribution Concept \\ i. Payment is based on application and investigation and verification. \\ ii. Ease the burden. \\ iii. Payment is only to individuals who are willing to undergo the rehabilitation and \\ monitoring process already arranged for them. \\ iv. As an effort to reestablish morals and faith. \\ Types of Help \\ i. Blemishing of Aqidah. \\ ii. Akhlak recovery assistance. \\ iii. Al-riqab liberation fund.
}

\title{
Opinion of Contemporary Scholars toward Zakat for Al-Riqab Aggregation
}

Islamic scholars set 'illah for eligibility to receive zakat under category of al-riqab is to release of the shackles (Abdul Halem, 2018). Azman Ab Rahman and Tengku Mansur (2016) tried to expand the scope of al-riqab to the liberation of the shackles of thought, economy, freedom and power.

The concrete opinion of some scholars and current fatwas, saying that al-riqab consists of three groups namely mukatab slaves, slaves and war prisoner. The 'illah is based on slavery. The opinion mentioned by Ibn 'Asyur (2000), 'Abd al-Latif Hamzah (1983), Yusuf al-Qardawi (2006), Wahbah al-Zuhaili (1991), Abdullah bin Mansur al-Ghufaili (2008) and several fatwa decisions such as fatwa Bayt al-Zakat Kuwait, Fatwa al-Lujnah al-Ba'imah li al-Buhuth al-'Ilmiyah wa al-'Ifta' Saudi Arabia, Fatwa Council of Indonesian Scholars, Fatwa Mufti of the Kingdom of Brunai and Fatwa About Selangor State Zakat Distribution System 1991.

According to Azman Ab Rahman \& Hasanah Abd Khafidz (2015) the slave of the mukatab is a servant promised by his master may be released provided that he pays a sum of money by instalments. The zakat property is given to the slave's master to settle the ransom debt. Allah SWT states:

Let those who cannot afford to marry keep themselves chaste until Allah enriches them out of His Bounty. And write out a deed of manumission for such of your slaves that desire their freedom in lieu of payment- if you see any good in them - and give them out of the wealth that Allah has given you. And do not compel your slave-girls to prostitution for the sake of the benefits of worldly life the while they desire to remain chaste. And if anyone compels them to prostitution, Allah will be Most Pardoning, Much Merciful (to them) after their subjection to such compulsion. (Surah al-Nur :24: 33)

Hayyun Nawawi et.al (2008), stated that in the book al Kasysyaf, a change in the use of $l i$ words (ownership) for the first four asnaf and the word fee (care or preservation) for the second four groups. The use of $l i$ words and this fee brings a clear difference in meaning. Thus, we can understand that distribution dealings to the first four groups (whose properties are only as owners) are considered to 
have finished by handing over the zakat parts to them. The second four groups are; care or preservation, which carries the implications of the implementation of continuous responsibility, management and supervision (Adnan et.al,2019).

Hence, the administrator of zakat distribution is fully responsible for managing the second of four groups (slaves promised conditional independence, persons owing, fi sabilillah and ibnu sabil) until they reach the meaning of the distribution of zakat property to them. Therefore, zakat distribution administrators are responsible for managing zakat distribution so that eligible people receive their share and ensure that zakat properties are not abused.

Muhammad Rashid Reda (2002) and Mahmud Syaltut (n.d.) argued that the efforts to free colonized Muslims can be taken from al-riqab asnaf. Their argument referred as; a colonialism is a far more dangerous on slavery, for the humanity because the slavery on the people and the nation involving thought, property, and reign.

Based on the analysis of opinions of scholars of mutaqaddimun, muta'akhkhirun and current, some conclusions can be made:

i) They agreed that slaves were the original meaning of al-riqab.

ii) They have differing opinions beyond the concept of slaves.

The majority scholars have rejected the ijtihad that give the meaning of al-riqab beyond the concept of slaves. While some of them accepted the concept of broadening the meaning of al-riqab, however, the meaning is still in the scope the term slaves, the Muslims prisoner of war status according to the rule of war during that time, changed to slave. However, some of the contemporary scholars trying to broaden the concept of al-riqab based on different 'illah. Muhammad Rashid Reda and Mahmud Syaltut believe that the colonial nation (Muslim's prisoners of war) has a greater harm than a slave. The method used is qiyas awlawi. Further, several fatwas and practices in Malaysia expanded the qiyas with 'illah term of caught. By expanding the concept of al-riqab which is beyond the meaning of slaves has been objected to by several contemporary scholars such as Yusuf al-Qaradawi (2006), Wahbah al-Zuhaili (1991), and Abdullah bin Mansur al-Ghufaili (2008).al-Ghufaili (2008) argued:

i) No dalil (evidence) and permissive argument to include people's independence taken from 'al-riqab' shares.

ii) There is no need to use al-riqab shares to indulge in Muslims colonized, as they can be taken from asnaf " $f i$ sabilillah" or from baitulmal general sources other than zakat.

iii) The domination of the non-muslims against Muslims has been occurred during the period of Prophet Muhammad and the salaf al-soleh scholars, but none cited them to include Muslims colonized referred as al-riqab.

According to Wahbah al-Zuhayli, the distribution to asnaf al-Riqab means releasing the al-Riqab alMukatab, al-Riqab and the prisoner of war at once. His views are based on the views of Ibn 'Abbas, Ibn 'Umar, Hassan al-Basri, Zuhri, Abu 'Ubaid and Madhab Hambali (Al-Zuhayli 1997). The rajih opinion is; al-riqab consisting of three groups namely mukatab slaves, sahaya slaves who want to be cultivated, and exploited Muslims (Arieff Salleh et.al 2013).

\section{The Principle of Determination Law against Zakat Distribution to Transexuals, Prostitutes and Gigolos}

Despite the confusion, this issue can be framed through the method of usul fiqh. This method is important because it able solve the problems in the contemporary context and issue, including those involved in prostitution activities (Zulkifli al-Bakri, 2012). The rajih arguments are:

i) The phrase 'wa fi al-riqab' in verse 60 surah al-Taubah is a common term which is not limit to one meaning only. The term of al-riqab according to Arabic means neck. While majazi (symbolic or metaphoric) means 
belonging slaves. This is because they are prisoned by their masters and no self-freedom. According to al-Razi of madhhab Syafi'i, if there is no evidence to specialize in a term, then the term of the title, majazi and musytarak in a pronunciation can be used in a time (al-Razi 1999 \& Qurrah Daghi 1992). Therefore, all conditions that lead to shackle act including prostitution etc., are included in the modern al-riqab category. Based on the previous and contemporary ijtihad among the scholars, they did not restrict the term of riqab to mukatab slaves only, yet there are scholars who also included the term of al-riqab also can be referred as the prisoner of war-Muslims (al-asir). This argument proves that the term of al-riqab is still communal and is not specialized for one meaning only (alQaradawi 1994).

iii) Opinions of scholars who specialize in al-riqab term only carrying the meaning of slaves are proven to be inconsistent in ijtihad related to those who are eligible to receive zakat. Thus, most of the contemporary scholars agreed to broaden the meaning of 'fi sabilillah' is beyond the original meaning of the nas i.e., for the soldiers to fight in war, to the wider meaning such as abroad students and so on in this current period. The same method is also used in the determination of the ruling of modern alriqab zakat.

iv) The tasarruf al-imam 'ala al-ra'iyyah manut bi al-maslahah is the main foundation of scholars for their ijtihad in case of contemporary zakat issues. It is intended that the category of asnaf which are mentioned in the Quran are remains relevant throughout the period. Al-Qaradawi (1994) also explained that the government's duties were bound to take care of the maslahah among people. Hence, the government and zakat personnel shall make maslahah for asnaf as their priority. In fact, there are rules for zakat, however have been permitted to change the rules if there are any beneficial to zakat and zakat asnaf (Adnan et.al, 2019). For example, fuqaha Syafi'i and Hambali have allowed the rulers or zakat personnel to sell animal-shaped f zakat if it is be afraid to perish or face high threats or costs of care (Ibn Qudamah, 1994 \& al-Nawawi, n.d.). However, it should be done after fulfilling several requirements to achieve the targetted maslahah. Maslahah should be seen not only to al-riqab. Even maslahah to other asnafs should also be preserved so that they are not being neglect because of it (al-riqab). Majority scholars claimed that if any of disagreement occurred between individual harm and the harms for society, then removal the harm for society is a priority. This is because to it covering to protect the society as well as individuals. On the other hand, protection towards individuals not certainly protected the community (Adnan et.al, 2017). This is based on the method:

$$
\text { يتحمل الضرر الخاص لدفع الضرر العام }
$$

"To prevent the harm that will befall the society, it is permissible to do harm that will befall a person (Zarqa' 1989).

This is supported by Imam al-Qurafi (1995): All sharia orders depend on the benefit of the prohibition of mafsadah. Thus, if the bond is on the 
lowest level, it is considered as sunnah and if on the highest level, then it is considered as wajib. If the maslahah is increasing, then it still considered as sunnah but higher level of sunnah, yet still not considered as wajib. In the case of the mafsadah, the lowest level is makruh. The hukum of makruh can be changed to haram if the level of mafsadah is also increased.

Meaning, that transexuals, prostitutes and gigolos are eligible to receive zakat under the asnaf al-riqab category to undergo the recovery process for them out of the shackles of ignorance they are facing.

Therefore, zakat funds collected from zakat payers should be used to assist those under the al-riqab category to be free from shackles of ignorance and freeing themselves.

\section{Discussion}

Rejecting mafsadah is obligatory for maslahah. This principle shows that Islam is very concerned about the social awareness versus individual awareness. Hence, the government should make a wise decision in aware on the significant changes in the social life among the society. If in any situation or issue which is no evidence of the Quran and al-Hadith that explains the hukum in detail. Therefore, this framework can be used as a platform for the distribution of zakat funds for better effectiveness.

\section{Conclusion}

Overall, zakat to transexuals, prostitutes and gigolos is an Islamic law should be category; for the purpose of helping them out of the disobedience crisis towards Islamic law and to continue in improving their future life. The rate of zakat is required to release on the agreed amount of debt. If the person has no property at all, then the zakat allocation must pay off all his debts. If he owns a little property, the zakat fund needs to cover on the agreed debt. This is only way his needs can be fulfilled. Apart from that, it is an innovation for the society to aware on the existence of asnaf al-riqab in new and different forms. Muslims are encouraged to be more creative and dynamic in expanding their understanding and dimensional interpretation of al-riqab. This is because the original scope of $a l$-riqab, is to free person who became slaves from their masters, which is needs to explore more in order to free person from the widespread harm in social life. Muslims who work hard and try to improve the use of al-riqab is a wise and practical person. In today's reality life, there are still many Muslims who live in a humiliation and misery situation. The systematic and careful implementation of the provision of asnaf al-riqab by the zakat administration in this country definitely will be able to elevate the dignity of zakat and Islam as the only religion to pour prosperity especially for Muslims in this country.

\section{References}

Al-Quran. (1994). Tafsir Pimpinan Ar-Rahman kepada pengertian Al-Quran. Kuala Lumpur: Bahagian Agama Jabatan Perdana Menteri Malaysia.,

Al-Babarti, Akmal al-Din Muhammad bin Mahmud al-Hanafi. (2007). al-'Inayah syarh al-hidayah. Sunt. Abu Mahrus 'Amru bni Mahrus. Jil. 1. Beirut: Dar al-Kutub al- 'Ilmiyah.

Al-Bahuti, Mansur bin Yunus bin Idris. (1996). Syarh muntaha al-'iradat. Cet. ke-2. Beirut: 'Alam alKutub.

Al-Baijuri, Ibrahim. (1999). Hasyiah Syeikh Ibrahim al-Baijuri 'ala syarh al-'Allamah Ibn alQasim alGhazzi 'ala matn al-Syeikh Abi Syuja'. Sunt. Muhammad 'Abd al-Salam Syahin. Jil. 1. Beirut: Dar al-Kutub al-'Ilmiyah. 
Al-Dusuqi, Muhammad bin Ahmad bin Urfah. (2003). Hasyiah al-Dusuqi 'ala al-syarh alkabir. Cet. ke2. Jil. 2. Beirut: Dar al-Kutub al-'Ilmiyah.

Al-Khatib, Muhammad al-Syarbini. (2008). al-Iqna'. Terj. M. Mujib et.al. Johor Bahru: Jahabersa.

Al-Khurasyi, Muhammad bin 'Abd Allah bin 'Ali. (1997). Hashiyah al-Khurasyi 'ala mukhtasar sidi Khalil. Sunt. Zakariya 'Umairat. Jil. 2. Beirut: Dar al-Kutub al- 'Ilmiyah.

Al-Marghinani, Burhan al-Din Abu al-Hasan 'Ali bin Abi Bakr bin 'Abd al-Jalil al-Rashdani. (1990). alHidayah syarh badayah al-mubtadi. Jil. 1. Beirut: Dar al-Kutub al-'Ilmiyah.

Al-Mawsu'ah. (1990). al-Fiqhiyah. Jil. 23. Kuwait: Wizarah al-Awqaf wa al-Shu'un al-Islamiyah.

Al-Nawawi, Abu Zakariya Muhyi al-Din bin Syaraf. (1995). Kitab al-majmu' syarh almuhadhdhab li al-Syirazi. Sunt. Muhammad Najib al-Muti'i. Beirut: Dar Ihya' al-Turath al-'Arabi.

Al-Nawawi, Abu Zakariya Muhyi al-Din bin Syaraf. T.th. Rawdat al-Talibin wa 'Umdat al-Muftin. Jil.4. Beirut: Dar al-Kutub al-'Ilmiyyah.

Al-Qaradawi, Yusuf. (2006). Fiqh al-zakat: Dirasah muqaranah li ahkamiha wa falsafatiha fi dau' alQur'an wa al-sunnah. Cet. ke-25. al-Qaherah: Maktabah Wahbah.

Al-Qurafi, Shihab al-Din Abu al-'Abbas Ahmad bin Idris bin 'Abd al-Rahman al-Sonhaji al-Misri. (2008). al-Zakhirah fi furu' al-Malikiyah. Ed. ke-2. Jil. 2. Beirut: Dar al-Kutub al-'Ilmiyah.

Al-Qurafi, Shihab al-Din Abu al-'Abbas Ahmad bin Idris bin 'Abd al-Rahman al-Sonhaji al-Misri. (1995). al-Ihkam Ihkam. Beirut: Dar al-Basha'ir al-Islamiyyah.

Al-Razi, Muhammad bin Abi Bakr bin 'Abd al-Qadir. (2000). Mukhtar al-sihah. al-Qaherah: Dar alHadith.

Al-Sharbiniyy, Muhammad bin Ahmad. (1994). Mughniyy al-Muhtaj Ila Marifah Maaniyy al-Alfaz alMinhaj. Dar al-Kutub al-Ilmiyyah.

Al-Zarqa', Mustafa Ahmad. (1989). Majallah Majma' al-Fiqh al-Islami. bil 3, vol. 1.

Al-Zayla'i, Fahr al-Din Uthman bin 'Ali al-Hanafi. (2000). Tabyin al-haqa'iq syarh kanz aldaqa'iq. Sunt. Ahmad 'Izzu 'Inayah. Beirut: Dar al-Kutub al-'Ilmiyah.

Al-Zuhayli, Wahbah. (1997). Al-Fiqh al-Islami Wa Adillatuhu. Dimasyq: Dar al-Fikr. Jil. 2. h. 2031.

Adnan, N. I. M., Kashim, M. I. A. M., Salleh, A. D., Jamsari, E. A., Ahmad, M. Y., \& Rahman, N. I. A. (2019). Sustainability of Zakah Distribution in Baitul Mal Aceh: Basic and Implementation Methods. International Journal of Academic Research in Business and Social Sciences, 9(1), $554-562$.

Adnan, N.I.M., Mohd Izhar Ariff Mohd Kashim, Zahri Hamat, Hafizuddin Muhd Adnan, Izwah Muhd Adnan, Fariza Md. Sham. (2019). The Potential for Implementing Microfinancing from the Zakat Fund in Malaysia, Humanities \& Social Sciences Reviews. 7(4). 542-548.

Adnan, N.I.M., Zahri Hamat, Mohammad Zaini Yahaya dan Mat Noor Mat Zain. (2017). Agihan Zakat Secara Mikro Kredit: Analisis Daripada Perspektif Maslahah, Journal of Contemporary Islamic Law. 2(1). 45-59.

Arieff Salleh bin Rosman, Azman Ab Rahman dan Muhamad Firdaus Ab Rahman. (2013). Garis Panduan Pengurusan Zakat Asnaf Riqab dan Gharimin: Satu Analisis Kontemporari.Geran Penyelidikan Isu Kefatwaan JAKIM. 99 Pusat Penyelidikan Fiqh Sains \& Teknologi (CFiRST) UTM dan Jabatan Mufti Negeri Johor.

Arieff Salleh bin Rosman, Azman Ab Rahman dan Muhamad Firdaus Ab Rahman. (2013). Kedudukan Ar-Riqab Sebagai Penerima Zakat Dalam Konteks Masa Kini. Makalah telah dibentangkan di Muzakarah Zakat Peringkat Kebangsaan siri1. 11 Disember 2013. Universiti Sains Islam Malaysia, Nilai, Negeri Sembilan.

Badr al-Din al-'Aini, Mahmud bin Ahmad bin Musa bin Ahmad bin al-Husayn. (2000). Al-Banayah syarh al-hidayah. Sunt. Ayman Saleh Sya'ban. Jil. 3. Beirut: Dar al-Kutub al-'Ilmiyah.

Benjamin, Harry. (1950). "Prostitution,” The Encyclopedia of Sexual Behaviour. Vol. II.

Gagnon, John H. (1958). "Sexual Behavior”. David L. Solls, ed., The International Encyclopedia of Social Sciences. Vol. 12.

Ibnu al-Humam, Kamal al-Din Muhammad bin 'Abd al-Wahid al-Sakandari. (1995). Syarh fath al-qadir. Sunt. 'Abd al-Razzaq Ghalib al-Mahdi. Jil. 2. Beirut: Dar al-Kutub al- 'Ilmiyah.

Ibnu 'Asyur, Muhammad al-Tohir. (2000). Tafsir al-tahrir wa al-tanwir. Jil. 10. Beirut: Mu'assasah alTarikh.

Ibnu Kathir, Abu al-Fidaa' Ismail bin Umar bin Kathir al-Qarsyhiyy al-Basriyy. (2003). Tafsir alQur'an al-Azim. Beirut: Dar al-Kutub al-cIlmiyyahTafsir 
Ibn Manzur, Abu al-Fadl Jamal al-Din Muhammad bin Mukram al-Misri. (1990). Lisan al- 'Arab. Beirut: Dar Sadir.

Ibn Muflih, Syams al-Din Abu 'Abd Allah Muhammad al-Maqdisi al-Hambali. (1997). Al-Furu'. Sunt. Abu al-Zahra' Hazim al-Qadi. Jil. 2. Beirut: Dar al-Kutub al-'Ilmiyah.

Ibnu Najjar, Taqiy al-Din Muhammad bin Ahmad al-Futuhi al-Hambali. (1999). Muntaha al- 'iradat fi jam' al-muqni' ma'a al-tanqih wa ziyadat. Sunt. 'Abd Allah bin 'Abd al-Hasan al-Turki. Beirut: Mu'assasah al-Risalah.

Ibnu Qudamah, Abu Muhammad 'Abd Allah bin Ahmad bin Muhammad al-Maqdisi. (1994). al-Mughni 'ala mukhtasar al-Kharqi. Sunt. 'Abd al-Salam Muhammad 'Ali Syahin. Beirut: Dar al-Kutub al'Ilmiyah.

James, Jennifer. (1977). "Prostitutes and Prostitution", Edward Sagarin \& Fred Montanino, eds., Deviants: Voluntary Actors in a Hostile World, Morristown, N. Jersey. General Learning Press.

J. Julian. (1980). Sosial Problems. Edisi ke-3. Prentice-Hall, Inc. New Jersey.

Lerner BW, Lerner KL, Lerner AW ed. (2006). Gender Issues and Sexuality: Essential Primary Sources. Thomson I Gale. Harvard University

May, Geoffrey. (1933). "Prostitution”, Encyclopedia of the Social Sciences. Vol. 12.

Mohamad Zainuddin, Muna munirah. (2020). Pembahagian Zakat kepada Golongan LGBT di Negeri Selangor. Latihan Ilmiah. Fakulti Pengajian Islam. Universiti Kebangsaan Malaysia.

Morris, Narval \& Gordan Hawkins. (1970). The Honest Polician's Guide to Crime Control. Chicago: University of Chicago Press.

Muhammad 'Abduh dan Muhammad Rashid Reda. (2002). Tafsir al-manar. Sunt. Samir Mustafa Rabab. Jil. 10. Beirut: Dar Ihya' al-Turath al-'Arabi.

Nagaraj, Shyamala and Yahya, Siti Rohani. (1995). The Sex Sector: An Unenumerated Economy. Penerbit Universiti Pertanian Malaysia.

Nichols, Bill. (1981). "American Gigolo: Transcendental Style and Narrative Form”, Film Quarterly. 34(4). 8-13. University of California Press. DOI: 10.2307/1212138.

Qal'aji, Muhammad Rawwas \& Qunaibiyy, Hamid Sadiq. (1988). Mu'jam Lughah al-Fuqaha'. Dar al-Nafaes.

Rehman, Javaid and Polymenopoulou, Eleni. (2013). Is Green a Part of the Rainbow? Sharia, Homosexuality and LGBT Rights in the Muslim World. Fordham International Law Journal. 37(1). 1-53.

Sayid Sabiq. (1981). Fikih Sunnah. P T ALMA’ARIF BANDUNG. ctk: keempat, jld:3.

Sanford, Jeremy. (1977). Prostitutes. London: Abacus Books.

Selangor Mufti Department. 2011. http://www.muftiselangor.gov.my/.

Suhakam. (2014). Study on Discrimination Against Transgender Persons Based in Kuala Lumpur and Selangor (Right to Education, Employment, Healthcare, Housing and Dignity).

Zakaria al-Ansari, Abu Yahya al-Syafi'i. (2001). Asna al-matalib syarh raud al-tolib. Sunt. Muhammad Muhammad Tamir. Jil. 2. Beirut: Dar al-Kutub al-'Ilmiyah.

Zahlan, Mohd Sulaiman; Zamzuri, Zainal Fikri; Md Isa, Mohd Fauzi \& Mahmud, Wahairi. 2010. Asnaf fi sabilillah : satu pengamatan agihan dana zakat di Malaysia.

Zulkifli bin Muhammad al-Bakri. (2013). Al-Riqab: Tafsiran aplikasi semasa dari sudut Syarak. Jurnal Pengurusan JAWHAR. 6(2). 